\title{
Major Salivary Gland Cancer Pathologic Primary Tumor TNM Finding v7
}

National Cancer Institute

\section{Source}

National Cancer Institute. Major Salivary Gland Cancer Pathologic Primary Tumor TNM

Finding V7. NCI Thesaurus. Code C89120.

A pathologic finding about one or more characteristics of major salivary gland cancer, following the rules of the TNM AJCC v7 classification system as they pertain to staging of the primary tumor. 